\title{
MANUFACTURE AND EVALUATION OF A LOCAL PEPPER SEED EXTRACTOR
}

\author{
Atef, A. E. *, E. M. Arif", and S. Mohamadain**
}

ABSTRACT

The research work is conducted at horticultural research institute, Dokki Giza Governorate to accomplish the machine work. The main objective of this work, is to manufacture and evaluate a locally seed extractor to minimize the extraction costs. The manufactured machine was evaluated as a function of change in drum speed and feed rate in terms of extraction efficiency, cleaning efficiency, chopping time, seed loses and operational cost.

The main results in this study can be abstracted as follows:

- Extraction efficiency increased from $95.5 \%$ to $99.1 \%$ by increasing the chopping drum speed from $3.75 \mathrm{~m} / \mathrm{s}$ to $5.7 \mathrm{~m} / \mathrm{s}$. Results showed that the washing process is very important in extracting seeds it increased extraction efficiency by 40 time.

- By increase the chopping drum speed from $3.75 \mathrm{~m} / \mathrm{s}$ to $5.7 \mathrm{~m} / \mathrm{s}$, the chopping consumed time decreased from $45 \mathrm{sec}$ to $20 \mathrm{sec}$, and washing time decreased from $540 \mathrm{sec}$ to $420 \mathrm{sec}$, respectively.

- Seed losses increased by increasing the chopping drum speed.

- There was not any mechanical damage of seed using the seed extractor. Seed total losses increased from $3.2 \%$ to $4.8 \%$ by increasing chopping drum speed from $3.75 \mathrm{~m} / \mathrm{s}$ to $5.7 \mathrm{~m} / \mathrm{s}$.

- There was a negative relation between chopping drum speed and cleaning efficiency.

- The operational cost of extractor was 8.53LE/h (185.1LE/ton). Meanwhile the manual extraction cost was $4375 \mathrm{LE} / \mathrm{ton}$.

\section{INTRODUCTION}

T $\mathcal{T}$ egetable is a life essential. Seed extraction process is an important criterion in the Egyptian vegetable, to minimize costs. Manual process is an Egyptian single method until now; it is

* Agric. Eng. Res. Institute.

${ }^{* *}$ Horti. Res. Institute, Vegetable Dept.

Misr J. Ag. Eng., October 2008 
costly and timely in production. Wehner and Humphries (1991) Stated that the construction of a single-fruit seed extractor for cucumber increases the speed and ease of removing seeds from individual, mature cucumbers for later drying and planting. The machine saves about 47 seconds/fruit compared to hand methods and is suited to handling single fruit. Gabani et al. (2002) concluded that to overcome the dependence on human labour for seed extraction which results in delayed processes, inadequate in supply and increased production cost, a mechanical seed extractor was test. The seed extraction cost by mechanical seed extraction is half that of manual seed. Kushwaha et al. (2005) resulted that the extraction efficiency $99.3 \%$ caused by square head bolted drum was found highest among all the three extraction mechanisms. Cleaning efficiency was found in the range of 97.9 to $99.6 \%$ for all crop variables. The value of seed loss $4.7 \%$ was low with the square head bolted drum in comparison to rasp-bar and rubberized extraction mechanism. Arif. E. M. (1999) resulted that by increasing cutting drum speed, cutting efficiency increased. Mohsenin (1986) stated that the differences in the physical and mechanical properties among seeds and fruit products are considered the basis for separation. The main objective of this study, is to manufacture and evaluate a locally seed extractor to substitute manual method to minimize the extraction costs in the Egyptian ministry of agriculture horticulture seeds production project.

\section{MATERIALS AND METHODOLOGY}

The extraction machine was designed and developed. It consisted of extraction mechanism and cleaning system mounted on a single frame as shown in Figure 1. Since the unit is to be used for seed purpose, minimum loss of quality was the major criteria in development and evaluation. Extraction of seed may be achieved using one of two modes: impact or squeezing or a combination of both.

\section{Pepper fruit specifications:}

Some pepper fruit (Hybrid $26 \times 29$ ) specifications which affect on the machine specifications and power required are illustrated in Table 1. 
Table (1): some pepper fruit specifications.

\begin{tabular}{|c|c|c|c|c|c|c|}
\hline No. & $\begin{array}{c}\text { Length } \\
\mathrm{cm} .\end{array}$ & $\begin{array}{c}\text { Width } \\
\mathrm{cm} .\end{array}$ & $\begin{array}{c}\text { Diameter } \\
\mathrm{cm} .\end{array}$ & $\begin{array}{c}\text { Penetration } \\
\text { force } \\
\mathrm{Kg} / \mathrm{cm}^{2} .\end{array}$ & $\begin{array}{c}\text { Weight } \\
\mathrm{g} .\end{array}$ & $\begin{array}{c}\text { Seeds } \\
\text { numbers }\end{array}$ \\
\hline 1 & 5.7 & 2.2 & 2.15 & 2.1 & 10 & 34 \\
2 & 6.3 & 2.3 & 2.1 & 2.23 & 12 & 40 \\
3 & 6.6 & 2.2 & 2.1 & 2.39 & 14 & 64 \\
4 & 5.6 & 2.1 & 2 & 2.46 & 9 & 29 \\
5 & 5.2 & 2 & 1.8 & 2.62 & 9 & 25 \\
6 & 5.8 & 2.4 & 2.5 & 1.85 & 16 & 97 \\
7 & 5.4 & 2.3 & 2.3 & 1.92 & 15 & 83 \\
8 & 6.8 & 2.6 & 2.7 & 1.69 & 20 & 120 \\
9 & 5.3 & 2.4 & 2.3 & 1.9 & 15 & 80 \\
10 & 6.3 & 2.2 & 2.1 & 2.62 & 12 & 40 \\
\hline Mean & 5.9 & 2.27 & 2.2 & 2.18 & 13.2 & 61 \\
\hline
\end{tabular}

Machine description and specifications:

In this study, the machine used for pepper seeds extracting (figs. 1 and 2) was constructed in private workshop at Zagazig city, El-Sharkia governorate under support of seeds extraction project ministry of agricultural. The extraction machine consists of frame, fruits hopper, chopping house, oscillating screen assemble, water tubes with nozzles, power transmission system and $2 \mathrm{Hp}$ electric motor. Pepper fruits are feed manually to the hopper and falls in the chopping house for cutting in three stages, one for two or three pieces the second for minimizing and the third for smallest, then the chopped materials falls on the screens solid section and moving by the effect of screen oscillating and water stream towards the perforated section to accomplish separating process using another water stream and manual shaking, then the separated seeds falls in the seed drawer and the chopped fruit skin falls behind the machine. General specifications of machine are shown in table 2.

\section{Adjustment of screen inclination angle:}

An oscillating screen was used to remove and separate pepper seeds from its chopped flesh. The screen is set inclined to the horizontal plane, the angle of inclination selected from the condition: 


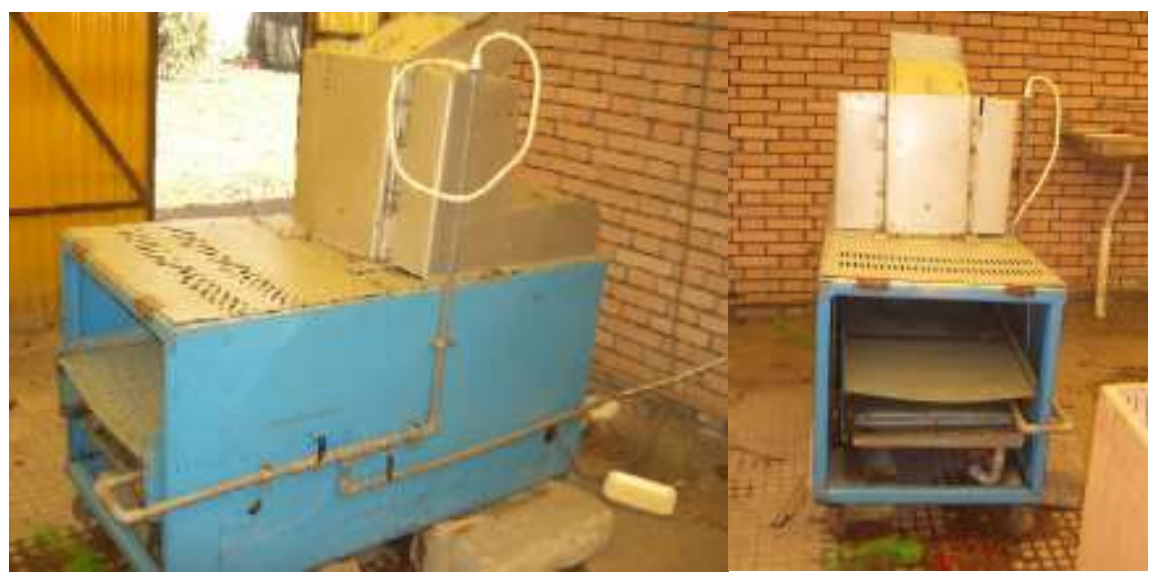

Fig. (1): Pepper seeds extractor.

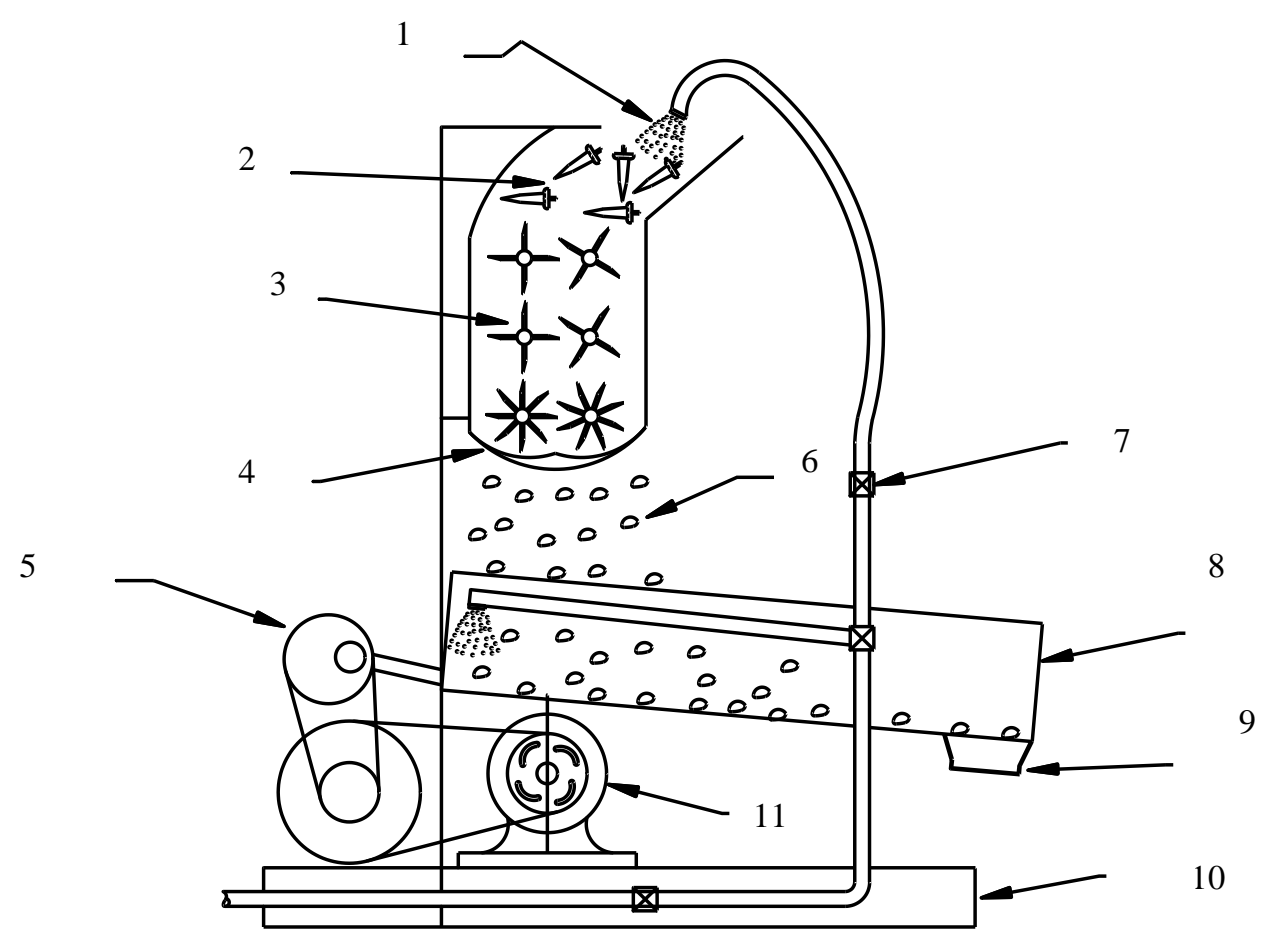

1- water shower, 2- pepper fruits, 3- cutting drum, 4- concave, 5- eccentric,

6- cutting materials, 7-valve, 8- screen, 9- seeds spout, 10-frame, 11- engine.

Fig. (2): Schematic diagram of pepper seeds extractor.

Misr J. Ag. Eng., October 2008 


\section{$\Psi \leq \theta \quad$ (Morghany 2004)}

Where: $\Psi=$ angle of screen on horizontal plane.

$\theta=$ friction angle between chopped materials and screen surface.

Coefficient of friction $(\mu)$ was measured for the chopped materials on galvanized steel according to (Abd El-Mageed and Abd Alla 1994):

$$
\mu=(\mathrm{P} / \mathrm{Q})=\tan \theta
$$

Where: $\mathrm{P}=$ force which makes the materials to start moving on the horizontal plane, $\mathrm{g}$.

$\mathrm{Q}=$ mass of materials, $\mathrm{g}$.

$\theta=$ angle of friction, $\operatorname{deg}(\theta=0.296 \mathrm{rad}$. (17 deg.) $)$.

From the pre-experiments, $\Psi$ was $0.226 \mathrm{rad}(13 \mathrm{deg})$ which was less than friction angle.

\section{Adjustment of screen rotational speed:}

370 rpm crank speed allow the chopped pepper be uniformly distributed over the screen surface and moves both forward and backward and not jumps off the screen surface, but toward the delivery end of the screen.

This machine designed to be easy to clean all seeds after work. To achieve this target, there are washing system which was used also for separate seeds from chopped flesh.

Table 2: General machine specifications:

\begin{tabular}{|c|c|}
\hline Item & Specification \\
\hline Overall length & $1300 \mathrm{~mm}$ \\
\hline Overall width & $570 \mathrm{~mm}$ \\
\hline Overall height & $1350 \mathrm{~mm}$ \\
\hline Power & $2 \mathrm{hp} \mathrm{electric} \mathrm{motor}$ \\
\hline Capacity & up to $150 \mathrm{~kg} / \mathrm{h}$ (pepper fruits) \\
\hline Labor requirement & $1-2$ men \\
\hline frame & $\begin{array}{l}1 \mathrm{~mm} \text { galvanized sheet metal and } 30 \mathrm{x} \\
30 \times 3 \mathrm{~mm} \text { angle iron }\end{array}$ \\
\hline
\end{tabular}

Performance of the manufactured machine was studied under the following variables: 
- Three different chopping drum speeds $(295,370$ and $445 \mathrm{rpm}$ $(3.09,3.87$ and $4.66 \mathrm{~m} / \mathrm{s})$ ).

- Four different feed rates $40,45,50$ and $55 \mathrm{~kg} / \mathrm{h}$.

Evaluation of the machine performance was carried out taking into consideration the following indicators:

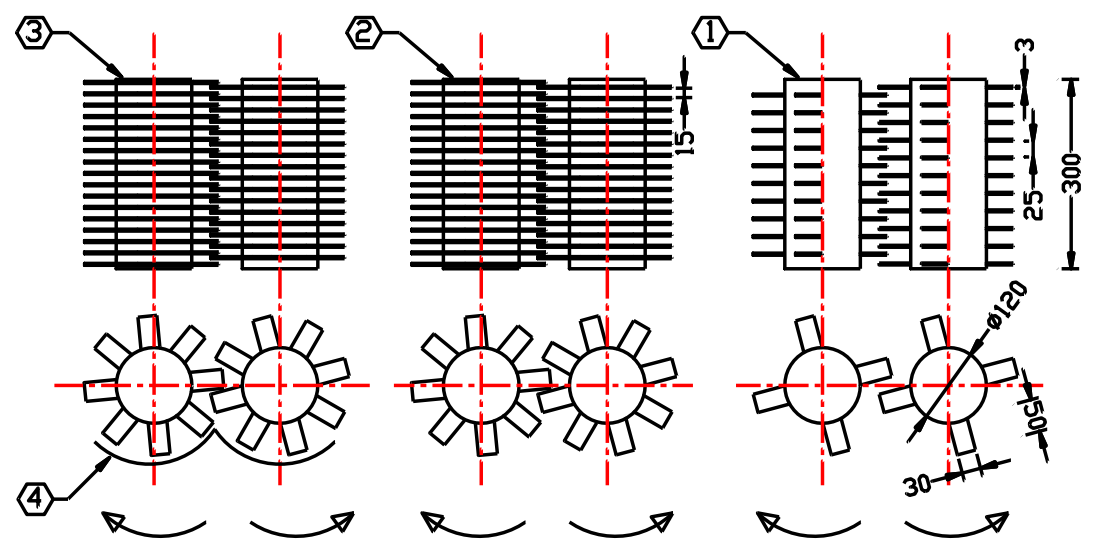

1- Upper chopping mechanism, 2- Middle chopping mechanism,

3- Final chopping mechanism, 4- Concave.

Fig. (3): Schematic diagram of chopping mechanism.

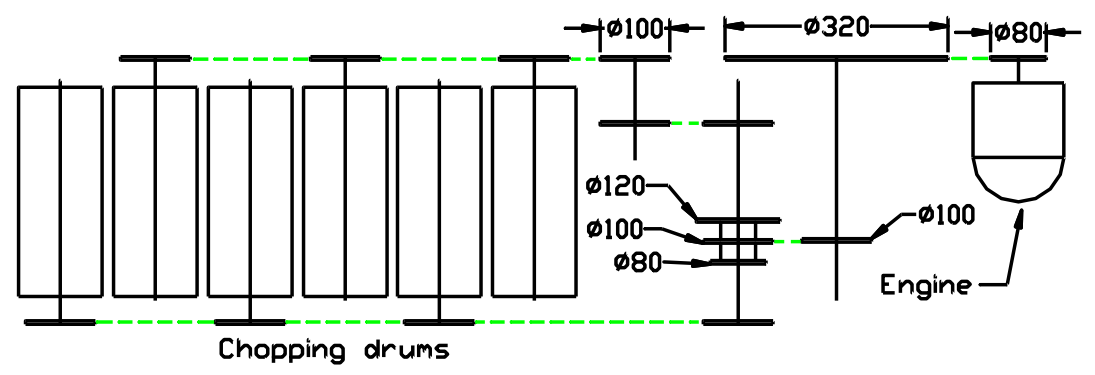

Fig. (4): Schematic diagram of power transmation.

Machine productivity:

Machine extracting productivity is determined by measuring the amount of extracting seeds in the unit time. 


\section{Extraction Efficiency:}

The extraction efficiency was determined on the basis of extracted and unextracted seed. Seed losses in the chopped materials, which not detached after separation in the cleaning system were extracted manually, cleaned and weighed using digital balance. The extraction efficiency was determined using the following expression (Kushwaha et al. (2005)):

Extraction efficiency, $\%=100-\mathrm{U}_{\mathrm{s}}$

$$
\text { Us, } \%=(\mathrm{C} / \mathrm{D}) .100
$$

Where: $U_{\mathrm{s}}=$ unextracted seed, $\%$.

$$
\begin{aligned}
& C=\text { Weight of unextracted seed, } g . \\
& D=\text { Weight of total seed input, } g .
\end{aligned}
$$

\section{Seed losses:}

Some seed loss outcome mechanically through impacting of the shredded material with cleaning system upper sieve. The seed losses were determined using the following relationship:

Seed losses, $\%=100-\left(\left(\left(\right.\right.\right.$ seed output $\left.\left.\left.+\mathrm{U}_{\mathrm{s}}\right) / \mathrm{D}\right) .100\right)$

\section{Seed damage:}

Samples of 50 seeds from each replication were tested in germination and comparing by the samples extracted manually (control). The dead seeds did not produce seedlings.

\section{Total losses:}

Seed total losses measured by sum the unextracted seeds $\left(U_{s}\right)$, seeds losses behind sieves $\left(\mathrm{S}_{1}\right)$ and mechanical damaged seeds $\left(\mathrm{D}_{\mathrm{s}}\right)$.

\section{Cost analysis:}

The operation cost of extractor was calculated as follows:

1- Machine cost:

Machine cost is $5000 \mathrm{LE}$, the life expectancy of the machine 5 years, and estimated working time 1000 hours per year. Machine cost $=1 \mathrm{LE} / \mathrm{h}$.

2- Operational costs:

The operational costs such as labor wage, electric consumed cost per hour, and water consumed cost per hour.

3- Taxes and overhead:

Taxes and overhead estimated to be $20 \%$ from machine cost. 
Total costs $=$ machine cost + operational cost + taxes and over head .

\section{RESULTS AND DISCUSSION}

The discussion will cover the results obtained under the following headings.

\section{Machine productivity:}

Machine extracting productivity is affected by both drum speed and feed rate, as shown in Fig. (5).

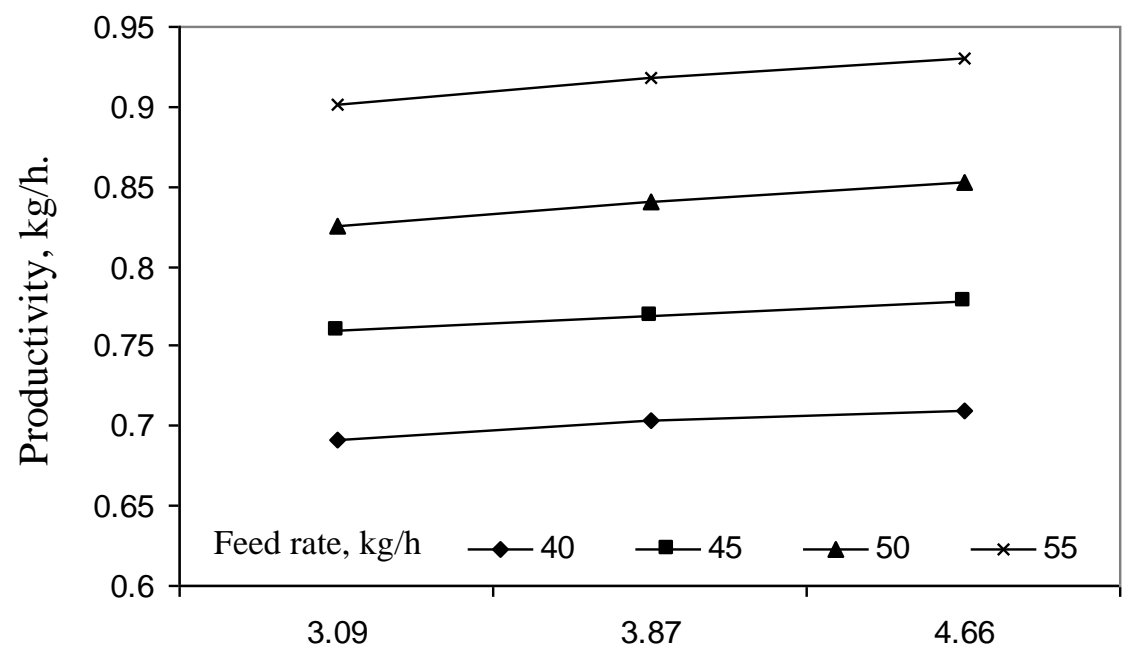

Drum speed, $\mathrm{m} / \mathrm{s}$.

Fig. (5): Effect of drum speed and feed rate on machine productivity $\mathrm{kg} / \mathrm{h}$.

The results indicated that the maximum productivity from extraction seeds of $0.930 \mathrm{~kg} / \mathrm{h}$ was attained under maximum feed rate of $55 \mathrm{~kg} / \mathrm{h}$ and high drum speed of $4.66 \mathrm{~m} / \mathrm{s}$.

\section{Extraction efficiency:}

The seed extraction efficiency increased with increase drum speed and decreased with increasing feed rate Fig. (6).

The maximum value of extraction efficiency of $94.7 \%$ was achieved with $4.66 \mathrm{~m} / \mathrm{s}$ drum speed and $40 \mathrm{~kg} / \mathrm{h}$ feed rate, meanwhile, the lowest extraction efficiency of $85.3 \%$ achieved with $3.09 \mathrm{~m} / \mathrm{s}$ drum speed and 55 $\mathrm{kg} / \mathrm{h}$ feed rate. It is may be due to increase the percentage of small size 
particles due increase the drum speed which improve the washing efficiency. It is clear that washing process is very important in extracting seeds from chopped flesh.

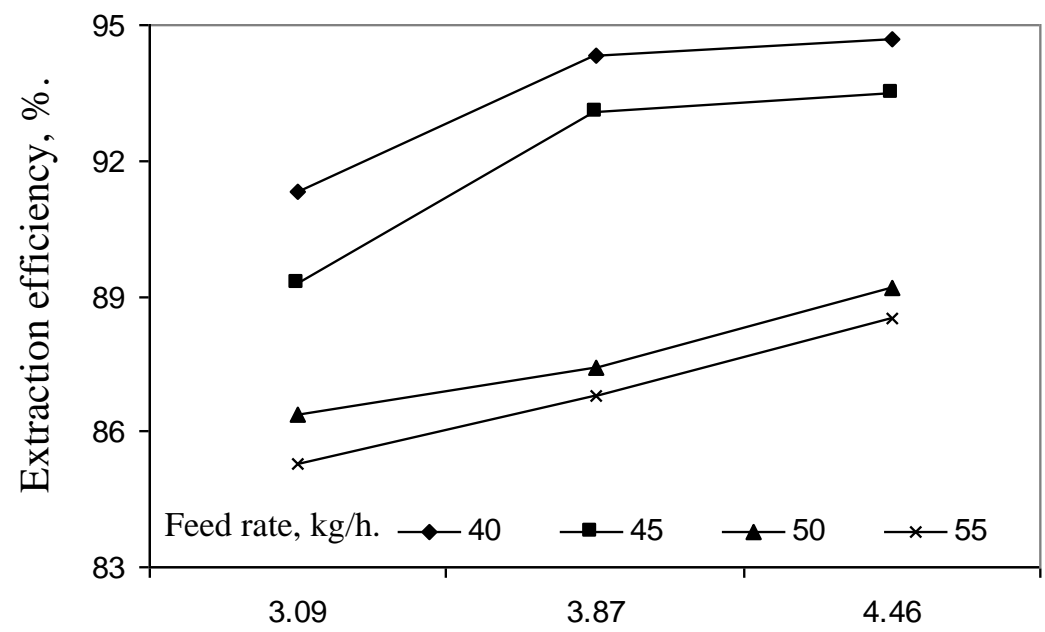

Drum speed, $\mathrm{m} / \mathrm{s}$.

Fig. (6): Effect of drum speed and feed rate on extraction efficiency, "\%".

\section{Seed Losses:}

Fig. (7) show the effect of drum speed and feed rate on the seed losses behind the screen. There was a positive relationship between chopping drum speed and feed rate with seed losses, the maximum value of seed losses $5.4 \%$ was achieved with $55 \mathrm{~kg} / \mathrm{h}$ feed rate and $4.66 \mathrm{~m} / \mathrm{s}$ drum speed ,while minimum value of $2.8 \%$ with $40 \mathrm{~kg} / \mathrm{h}$ feed rate and $3.09 \mathrm{~m} / \mathrm{s}$ drum speed.

It is may be due increasing seed speed by increasing drum speed . There was not any mechanical damage on seeds when using the seed extractor (the results using germination test).

\section{Cost analysis:}

The operation cost of extractor was calculated as follows:

1- Machine cost:

Machine cost is $5000 \mathrm{LE}$, the life expectancy of the machine 5 years, estimated working time 1000 hours per year. Machine cost $=1 \mathrm{LE} / \mathrm{h}$.

2- Operational costs:

Misr J. Ag. Eng., October 2008 
Two labors $(25 \mathrm{LE}$ for each/day $\cong 3.13 \mathrm{LE} / \mathrm{h}$ ) $6.3 \mathrm{LE} / \mathrm{h}, 0.8 \mathrm{LE}$ for electric consumed per hour, and 0.38 for water consumed per hour.

Operational costs $=6.3+0.8+0.38=7.48 \mathrm{LE} / \mathrm{h}$.

3- Taxes and overhead:

Taxes and overhead estimated to be $20 \%$ from machine cost. Taxes and overhead $=0.05 \mathrm{LE} / \mathrm{h}$.

Total costs $=1+7.48+0.05=8.53 \mathrm{LE} / \mathrm{h}$.

Extraction spantime $=21.7 \mathrm{~h} /$ ton.

Total costs $=21.7 \times 8.53=185.1 \mathrm{LE} /$ ton .

Manual extraction costs:

One labor ( $35 \mathrm{~L} /$ day) used to extract the seeds from $8 \mathrm{~kg}$ pepper fruits per day, it is mean (280 LE/day (35/8)) 4375LE/ton.

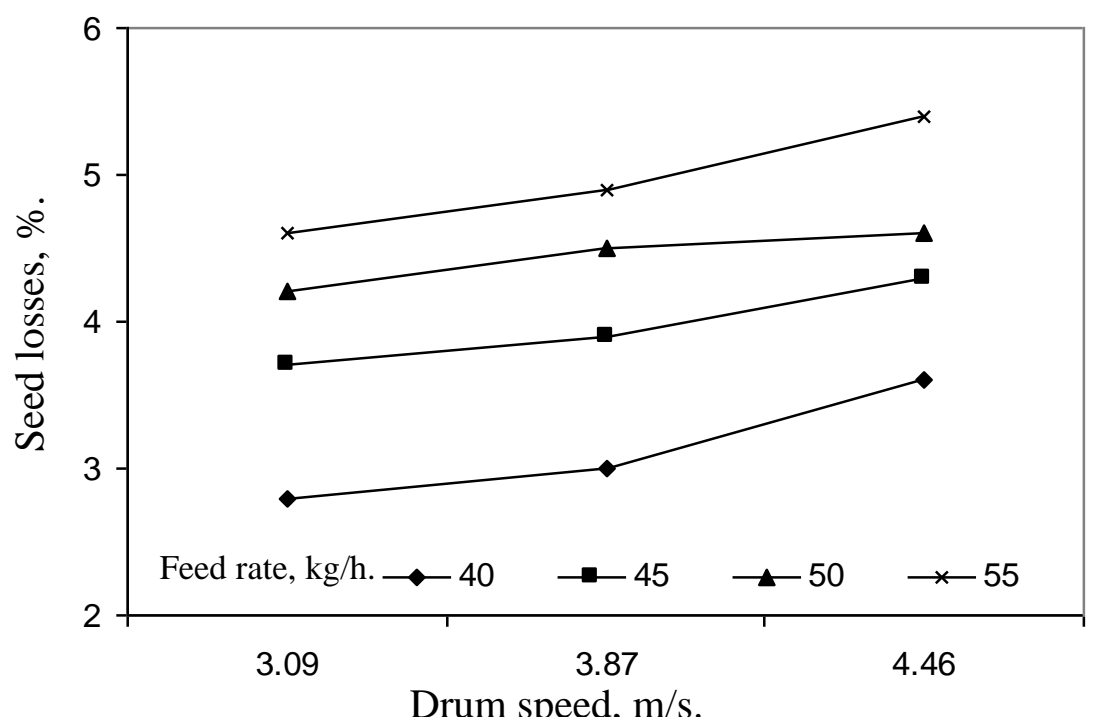

Fig. (7): Effect of drum speed and feed rate on the seed losses percentage.

\section{CONCLUSIONS}

Results can be concluded as follow:

- There is a positive relationship between drum speed and feed rate on machine productivity and seed losses. Maximum machine productivity and losses were $0.930 \mathrm{~kg} / \mathrm{h}$ and $5.4 \%$ achieved at $4.66 \mathrm{~m} / \mathrm{s}$ and $55 \mathrm{~kg} / \mathrm{h}$ feed rate. 
- The drum speed have a positive relationship with extraction efficiency, while the feed rate have negative relationship with extraction efficiency .

- There was not any mechanical damage of seed using the seed extractor

- The operational cost of extractor was $8.53 \mathrm{LE} / \mathrm{h}$ (185.1LE/ton). Meanwhile the manual extraction cost was 4375LE/ton.

- It is obvious from results that drum speed of $3.87 \mathrm{~m} / \mathrm{s}$ and feed rate of $45 \mathrm{~kg} / \mathrm{h}$ achieved acceptable values from machine productivity $3 \mathrm{~kg} / \mathrm{h}$, extracting efficiency $93.1 \%$ and $3.9 \%$ seed losses. And the extraction process must be done during the washing

process.

\section{REFERENCES}

Wehner, T. C. and E. G. Humphries (1991). A single-fruit seed extractor for cucumbers. (PDF), Cuke. hort. ncsu. edu.

Gabani, S. H., S. C. B. Siripurapu, R. F. Sutar and G. K. Saxena (2002). Development and evaluation of a mechanical seed extractor. Agric. Mech. Asia. Afr. Lat. Am., Vol. 33; No. 2; pp: 22 - 24.

Kashwaha, H. L., A. P. Srivastava, H. Singh (2005). Development and performance evaluation of an Okra seed extractor. Agric. Eng. International. The CIGR e-journal. Manuscript PM 05 001. Vol. VII. December, pp:1 - 12.

Arif, E. M. (1994). Studying concave drum factors and operation of a locally manufactured thresher and their effect on threshing efficiency. M. Sc. Thesis, Agric. Eng. Dept., Fac. of Agric., Ain Shams Univ.

Arif, E. M. (1999). Developing and evaluation of the chopper for composting. Ph. D. Thesis, Agric. Eng. Dept., Fac. of Agric., Ain Shams Univ.

El-Morghany, H. A. (2004). Developing of a combination unit for harvesting and gathering potatoes crop. $\mathrm{Ph}$. D. thesis, Agric. Eng. Dept., Fac. of Agric., Zag. Univ. PP $21-39$. 
Mohsenin, N. N. (1986). Physical properties of plant and animal materials. New York: Gordon and breach Science Publishers.

\section{الملخص العربي}

\section{دراسة آلة إستخلاص بذور القلقل}

\section{عاطف أحمد عليوة" الأمين محمد عارف " صلاح محمدين"*}

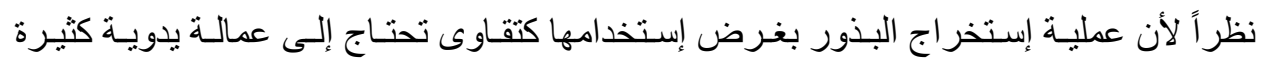

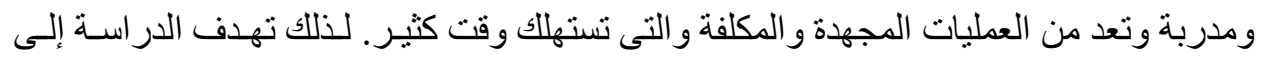

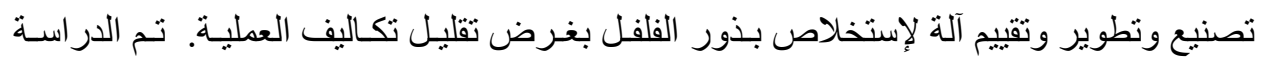

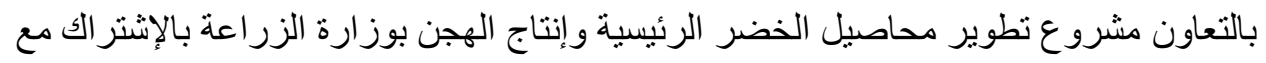

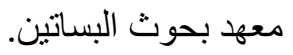

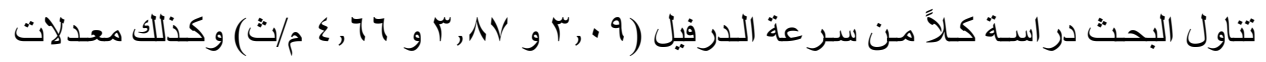

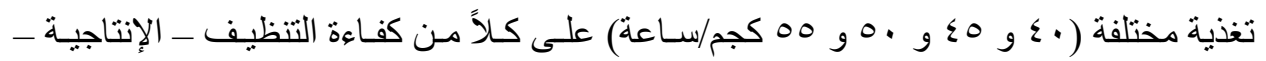

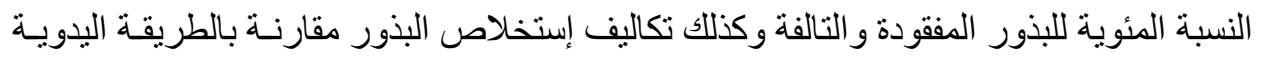

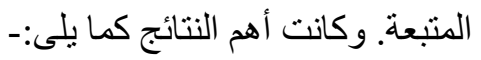

وجود علاقة إيجابية لكل من سر عة الدرفيل ومعدلات التغذيـة على إنتاجيـة الآلـة وكذللك نسبة

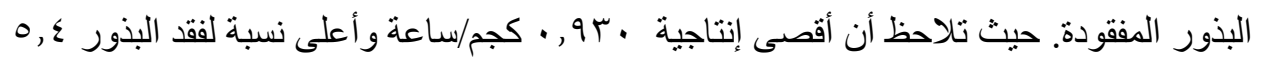

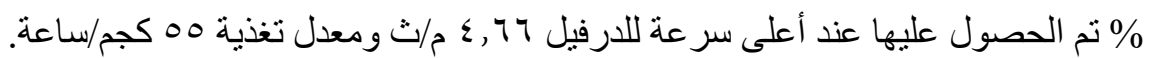

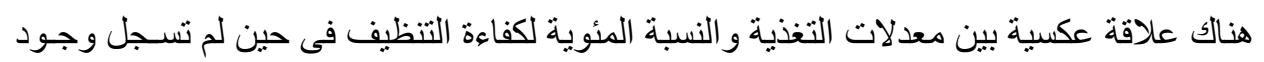

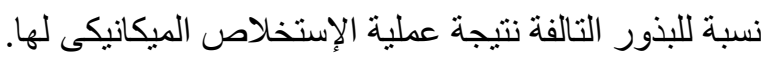

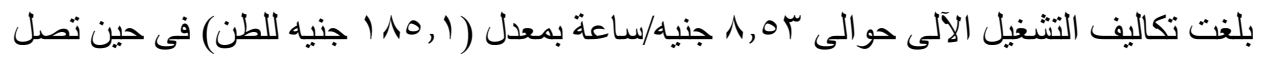

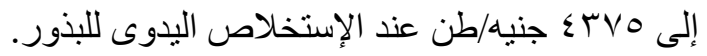

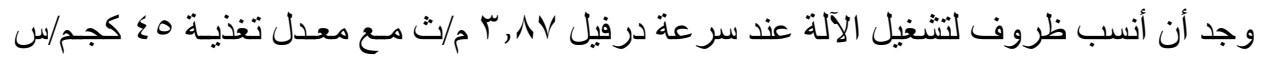

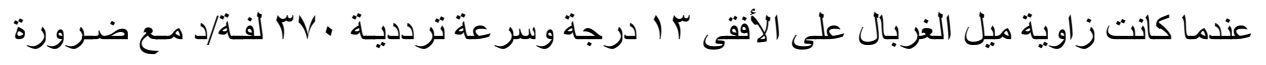

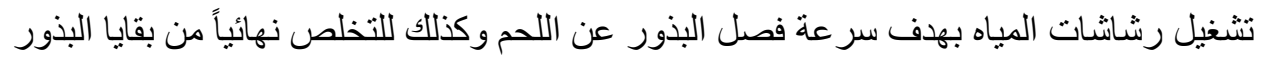
بعد الإنتهاء من عملية الإستخلاص منعاً للخلط بين الأصناف.

* رئحث أول بمعهد بحوث الهندسة الزر اعية.

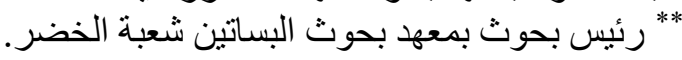

